\title{
THE
}

\section{A Simple and Efficient Synthesis of 2,3-Diarylnaphthofurans using Sequential Hydroarylation/Heck Oxyarylation}

\author{
V. Kameshwara Rao \\ Gamesh M. Shelke \\ Rakesh Tiwari \\ Keykavous Parang \\ University of Rhode Island, kparang@uri.edu \\ Anil Kumar
}

Follow this and additional works at: https://digitalcommons.uri.edu/bps_facpubs

\section{The University of Rhode Island Faculty have made this article openly available. Please let us know how Open Access to this research benefits you.}

This is a pre-publication author manuscript of the final, published article.

Terms of Use

This article is made available under the terms and conditions applicable towards Open Access Policy Articles, as set forth in our Terms of Use.

\section{Citation/Publisher Attribution}

Rao, V. K., Shelke, G. M., Tiwari, R., Parang, K., \& Kumar, A. (2013). A Simple and Efficient Synthesis of 2,3-Diarylnaphthofurans Using Sequential Hydroarylation/Heck Oxyarylation. Organic Letters, 15(9), 2190-2193. doi: $10.1021 / 01400738$ r Available at: http://dx.doi.org/10.1021/ol400738r

This Article is brought to you for free and open access by the Biomedical and Pharmaceutical Sciences at DigitalCommons@URI. It has been accepted for inclusion in Biomedical and Pharmaceutical Sciences Faculty Publications by an authorized administrator of DigitalCommons@URI. For more information, please contact digitalcommons-group@uri.edu. 


\title{
A Simple and Efficient Synthesis of 2,3-Diarylnaphthofurans using Sequential Hydroarylation/Heck Oxyarylation
}

\author{
V. Kameshwara Rao ${ }^{\dagger}$, Ganesh M. Shelke ${ }^{\dagger}$, Rakesh Tiwari $^{\ddagger}$, \\ Keykavous Parang ${ }^{\ddagger, *}$, Anil Kumar ${ }^{\dagger, *}$ \\ ${ }^{\dagger}$ Department of Chemistry, Birla Institute of Technology and Science, Pilani, Pilani- \\ 333 031, Rajasthan, India and Department of biomedical and Pharmaceutical \\ Sciences, College of Pharmacy,University of Rhode Island, Kingston 02881, RI, USA \\ E-mail: anilkumar@pilani.bits-pilani.ac.in,kparang@uri.edu
}

Received Date (will be automatically inserted after manuscript is accepted)

\section{ABSTRACT}

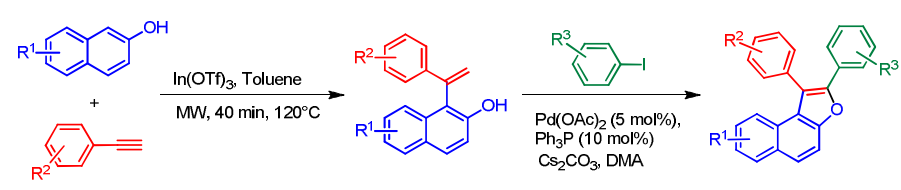

An efficient and simnple strategy has been developed for the synthesis of 2,3-diarylnaphthofurans using sequential hydroarylation of naphthols and alkynes in the presence of $\ln (\mathrm{OTf})_{3}$ under microwave irradiation followed by one-pot Heck-oxyarylation of generated 1-substituted- $\alpha$-hydroxy styrenes.

Benzofurans and naphthofurans are important classes of heterocyclic compounds that are present as key structural motifs in many natural products, as well as in synthetic pharmaceutical compounds. ${ }^{[1,}{ }^{2]}$ Biological significance of these motifs have been clearly exemplified by natural products and synthetic compounds, such as Furomollugin, ${ }^{3}$ Viniferifuran, ${ }^{4}$ Anigopreissin $A^{5}$ and 7methoxy-2-nitronaphtho[2,1-b]furan (R7000) ${ }^{6}$ (Figure 1). Naphthofuran is a powerful paradigm in the development and design of potentially active compounds for anticancer, ${ }^{1}$ regulators of the nuclear receptor $\mathrm{HNF} 4 \alpha{ }^{7}$ and imaging agents for $\beta$-amyloid plaques in the brain. ${ }^{8}$

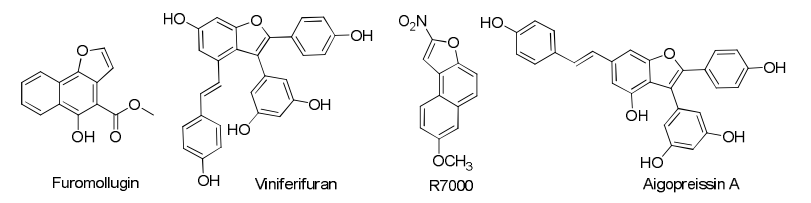

Figure 1. Structure of bioactive benzofuran and naphthofurans
Considerable attention has been directed toward the synthesis of compounds with benzofuran and naphthofuran framework because of their remarkable biological activities. ${ }^{9-16}$ Acardi et al. described the first palladium-catalyzed intramolecular cyclization of arylsubstituted alkynes possessing a hydroxyl group at ortho-position to the triple bond for the synthesis of 2,3diarylbenzofuran. ${ }^{17}$ Since then transition metal catalyzed coupling/ cyclization of suitably functionalized alkynes as starting materials has been focus for the synthesis of 2,3diarylbenzofurans and 2,3-diarylnaphthofurans. ${ }^{18-21} \mathrm{~A}$ number of methods have been developed for synthesis of 2,3-diarylbenzofurans but synthetic routes for naphthofurans are limited, ${ }^{11,14}$ and synthesis of diversified naphthofurans still presents major challenge in organic synthesis.

Encouraged by the illustrated biological and synthetic interest in 1,2-diarylnaphtho[2,1-b]furans and prompted by the recent results for metal catalyzed $\mathrm{C}-\mathrm{H}$ activation reactions, we envisaged a novel synthetic pathway to 2,3diarylnaphthofurans starting from 2-naphthols (1), aryl alkynes (2), and haloarenes (4). It was expected that 
hydroarylation of $\mathbf{2}$ with $\mathbf{1}$ in the presence of Lewis acids will generate $\alpha$-hydroxy styrenes (3). ${ }^{22-27}$ Heckoxyarylation of $\mathbf{3}$ with $\mathbf{4}$ will afford desired 2,3diarylnaphthofurans (Scheme 1). We report herein a simple and efficient method for the synthesis of 2,3diarynaphthofurans by sequential hydroarylation/Heckoxyarylation. To the best of our knowledge, this is the first report of the synthesis of diversified diarylnaphthofurans using sequential diarylation rections.

Scheme 1. Retrosynthetic analysis of 1,2-diarylnaphthofurans

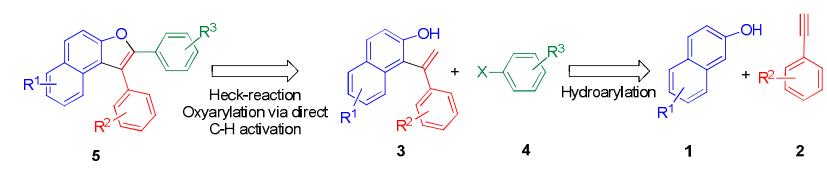

In our initial investigation, 2-naphthol (1a), phenylacetylene (2a) and iodobenzene (4a) were used as substrates to form 2,3-diphenylnaphthofuran (5a) using $\mathrm{Yb}(\mathrm{OTf})_{3}$ as a catalyst for hydroarylation and $\mathrm{Pd}(\mathrm{OAc})_{2}$ for in situ Heck-oxyarylation. This strategy was unsuccessful since hydroarylation did not happen under these conditions. Thus, first the reaction conditions for hydroarylation of $\mathbf{2 a}$ with $\mathbf{1 a}$ to give 1-(1phenylvinyl)naphthalen-2-ol (3a) were optimized using different Lewis acid catalysts (Table 1). Among different metal triflates screened, $\mathrm{Cu}(\mathrm{OTf})_{2}, \mathrm{Sc}(\mathrm{OTf})_{3}$, and $\mathrm{Bi}(\mathrm{OTf})_{3}$ afforded $3 \mathbf{a}$ in good to moderate yields (30-81\%, Table 1 , entries 7-9). In the case of $\mathrm{Cu}(\mathrm{OTf})_{2}$ homocoupled product of 2a was also obtained in $30 \%$ yield along with 3a. An excellent yield of 3a $(91 \%)$ was obtained by the use of $\operatorname{In}(\mathrm{OTf})_{3}(10 \mathrm{~mol} \%)$ under microwave irradiation in toluene (Table 1 , entry 10 ).

Table 1. Optimization of Hydroarylation Conditions for $\mathbf{3 a}$.

\begin{tabular}{|c|c|c|c|c|c|}
\hline Entry & Catalyst & $\begin{array}{l}\text { Mol } \\
(\%)\end{array}$ & $\begin{array}{l}\text { Time } \\
(\min )\end{array}$ & Solvent & Yield $^{\mathrm{a}}(\%)$ \\
\hline 1 & $\mathrm{Yb}(\mathrm{OTf})_{3}$ & 10 & 40 & Toluene & $-b, c$ \\
\hline 2 & $\mathrm{Y}(\mathrm{OTf})_{3}$ & 10 & 40 & Toluene & Trace \\
\hline 3 & $\mathrm{Ce}(\mathrm{OTf})_{3}$ & 10 & 40 & Toluene & $-\mathrm{b}$ \\
\hline 4 & $\operatorname{Ln}(\mathrm{OTf})_{3}$ & 10 & 40 & Toluene & Trace \\
\hline 5 & $\mathrm{Gd}(\mathrm{OTf})_{3}$ & 10 & 40 & Toluene & 10 \\
\hline 6 & $\mathrm{Zn}(\mathrm{OTf})_{2}$ & 10 & 40 & Toluene & Trace \\
\hline 7 & $\mathrm{Cu}(\mathrm{OTf})_{2}$ & 10 & 40 & Toluene & 30 \\
\hline 8 & $\mathrm{Sc}(\mathrm{OTf})_{3}$ & 10 & 40 & Toluene & 81 \\
\hline 9 & $\mathrm{Bi}(\mathrm{OTf})_{3}$ & 10 & 40 & Toluene & 59 \\
\hline 10 & $\operatorname{In}(\text { OTf })_{3}$ & 10 & 40 & Toluene & $91(76)^{\mathrm{c}}$ \\
\hline 11 & $\operatorname{In}(\mathrm{OTf})_{3}$ & 10 & 20 & Toluene & 66 \\
\hline 12 & $\operatorname{In}(\mathrm{OTf})_{3}$ & 5 & 40 & Toluene & 61 \\
\hline 13 & $\operatorname{In}(\mathrm{OTf})_{3}$ & 10 & 20 & $\mathrm{ACN}$ & 79 \\
\hline 14 & $\operatorname{In}(\mathrm{OTf})_{3}$ & 10 & 20 & $\mathrm{THF}$ & 71 \\
\hline
\end{tabular}

It is noteworthy to mention that when the hydroxyl group of naphthol was converted to methoxy and acetoxy, hydroarylation did not occur to give the corresponding 1substituted-a-hydroxy styrene. It is expected that the hydroarylation reaction proceeds through the mechanism as proposed in literature. ${ }^{23,28}$

Following the optimized reaction conditions for the hydroarylation, 1a and 7-methoxynaphthol (1b) were hydroarylated with different 4-substituted phenylacetylenes (2a-c) in the presence of $\operatorname{In}(\mathrm{OTf})_{3}$ to give the corresponding 1 -substituted- $\alpha$-hydroxy styrenes (3a-f) in high yields (85-95\%, Table 2).

The structures of 3a-f were confirmed by NMR and high-resolution mass spectrometry (HRMS) (Supporting information). Vinylic $\mathrm{CH}_{2}$ protons for 3a resonated at $\delta$ 6.35 and 5.53 with a splitting constant of $1.5 \mathrm{~Hz}$, and the phenolic proton resonated at $\delta 5.61$ as a singlet in the ${ }^{1} \mathrm{H}$ NMR spectra. In the ${ }^{13} \mathrm{C} \mathrm{NMR}$, a total of 16 carbons appeared, which is as expected for the structure of $\mathbf{3 a}$, and a peak at 247.1126 for $[\mathrm{M}+\mathrm{H}]^{+}$ion in HRMS spectra further confirmed the structure of $\mathbf{3 a}$.

Table 2. Synthesis of 1-Vinylnaphthols. ${ }^{a}$

\begin{tabular}{|c|c|c|c|c|c|}
\hline Entry & $\mathrm{R}^{1}$ & $\mathrm{R}^{2}$ & Product & $\begin{array}{l}\text { Time } \\
(\min )\end{array}$ & $\begin{array}{l}\text { Yield } \\
(\%)^{\mathrm{b}}\end{array}$ \\
\hline 1 & $\mathrm{H}$ & $\mathrm{H}$ & $3 \mathbf{a}$ & 40 & 91 \\
\hline 2 & $\mathrm{H}$ & 4- $\mathrm{CH}_{3}$ & $\mathbf{3 b}$ & 40 & 92 \\
\hline 3 & $\mathrm{H}$ & $4-\mathrm{OCH}_{3}$ & $3 c$ & 30 & 95 \\
\hline 4 & 7- $\mathrm{OCH}_{3}$ & $\mathrm{H}$ & 3d & 35 & 86 \\
\hline 5 & $7-\mathrm{OCH}_{3}$ & $4-\mathrm{CH}_{3}$ & $3 e$ & 35 & 85 \\
\hline 6 & $7-\mathrm{OCH}_{3}$ & $4-\mathrm{OCH}_{3}$ & 3f & 30 & 86 \\
\hline \multicolumn{6}{|c|}{$\begin{array}{l}{ }^{\mathrm{a}} \text { Reaction conditions: } 1(1.39 \mathrm{mmol}), 2(1.66 \mathrm{mmol}), \operatorname{In}(\mathrm{OTf})_{3}(78 \\
\mathrm{mg}, 10 \mathrm{~mol} \%) \text {, toluene }(2 \mathrm{~mL}) \mathrm{MW} \text { at } 120^{\circ} \mathrm{C}, 30 \mathrm{psi} \text {; }{ }^{\mathrm{b}} \text { Isolated yield. }\end{array}$} \\
\hline
\end{tabular}

Next, the reaction conditions were standardized for a one-pot sequential palladium-catalyzed cross-coupling reaction and oxyarylation (Heck-oxyarylation) of 1substituted- $\alpha$-hydroxy styrenes (3) with haloarenes (4) to afford the desired 2,3-disubstituted naphthofurans. The model reaction performed with $\mathbf{3 a}$ using iodobenzene (4a) in the presence of $\mathrm{Pd}(\mathrm{OAc})_{2}(5 \mathrm{~mol} \%)$ and potassium carbonate ( 2 equiv) in $N, N$-dimethylacetamide (DMA) resulted in an $18 \%$ yield of 1,2-diphenylnaphtho[2,1b]furan (5a) after $14 \mathrm{~h}$ at $140{ }^{\circ} \mathrm{C}$. When triphenylphosphine $\left(\mathrm{PPh}_{3}\right)$ was used as a ligand in the above reaction, in contrast to our earlier result, 5a was obtained in $50 \%$ yield. Further optimization of the reaction condition using different palladium catalysts, ligands, bases, and solvents (Table 3) led to improvement in the yield of $\mathbf{5 a}$. The highest yield of $\mathbf{5 a}$ (72\%, entry 2) was obtained by using $\mathrm{Pd}(\mathrm{OAc})_{2}(5 \mathrm{~mol} \%)$ in the presence of $\mathrm{PPh}_{3}$ and $\mathrm{Cs}_{2} \mathrm{CO}_{3}$ in DMA. The yield of 5a was moderate to good $(27-64 \%)$ with other palladium catalysts such as $\mathrm{PdCl}_{2}, \mathrm{Pd}\left(\mathrm{PPh}_{3}\right)_{2} \mathrm{Cl}_{2}, \mathrm{Pd}(\mathrm{dba})_{2}$ and $\mathrm{Pd}(\mathrm{dppf}) \mathrm{Cl}_{2}$ (Table 3, entry 2-4, 18). 
Table 3. Optimization of Heck-oxyarylation Condition for $\mathbf{5 a}{ }^{a}$

\begin{tabular}{|c|c|c|c|c|c|}
\hline Entry & Catalyst & Ligand & Base & Solvent & $\begin{array}{l}\text { Yield } \\
(\%)^{\mathrm{b}}\end{array}$ \\
\hline 1 & $\mathrm{Pd}(\mathrm{OAc})_{2}$ & - & $\mathrm{Cs}_{2} \mathrm{CO}_{3}$ & DMA & 18 \\
\hline 2 & $\operatorname{Pd}\left(\mathrm{OAc}_{2}\right.$ & $\mathbf{P P h}_{3}$ & $\mathrm{Cs}_{2} \mathrm{CO}_{3}$ & DMA & 72 \\
\hline 3 & $\mathrm{PdCl}_{2}$ & $\mathrm{PPh}_{3}$ & $\mathrm{Cs}_{2} \mathrm{CO}_{3}$ & DMA & 27 \\
\hline 4 & $\mathrm{Pd}\left(\mathrm{PPh}_{3}\right)_{2} \mathrm{Cl}_{2}$ & $\mathrm{PPh}_{3}$ & $\mathrm{Cs}_{2} \mathrm{CO}_{3}$ & DMA & 59 \\
\hline 5 & $\operatorname{Pd}(\mathrm{dba})_{2}$ & $\mathrm{PPh}_{3}$ & $\mathrm{Cs}_{2} \mathrm{CO}_{3}$ & DMA & 64 \\
\hline 6 & $\mathrm{Pd}(\mathrm{OAc})_{2}$ & $\mathrm{PPh}_{3}$ & $\mathrm{KOH}$ & DMA & 15 \\
\hline 7 & $\mathrm{Pd}(\mathrm{OAc})_{2}$ & $\mathrm{PPh}_{3}$ & $\mathrm{Et}_{3} \mathrm{~N}$ & DMA & Trace \\
\hline 8 & $\mathrm{Pd}(\mathrm{OAc})_{2}$ & $\mathrm{PPh}_{3}$ & $\mathrm{~K}_{2} \mathrm{CO}_{3}$ & DMA & 50 \\
\hline 9 & $\mathrm{Pd}(\mathrm{OAc})_{2}$ & $\mathrm{PPh}_{3}$ & $\mathrm{tBuOK}$ & DMA & 64 \\
\hline 10 & $\mathrm{Pd}(\mathrm{OAc})_{2}$ & $\mathrm{PPh}_{3}$ & $\mathrm{Cs}_{2} \mathrm{CO}_{3}$ & DMF & 48 \\
\hline 11 & $\mathrm{Pd}(\mathrm{OAc})_{2}$ & $\mathrm{PPh}_{3}$ & $\mathrm{Cs}_{2} \mathrm{CO}_{3}$ & Toluene & 35 \\
\hline 12 & $\mathrm{Pd}(\mathrm{OAc})_{2}$ & Phen $^{c}$ & $\mathrm{Cs}_{2} \mathrm{CO}_{3}$ & DMA & 50 \\
\hline 13 & $\mathrm{Pd}(\mathrm{OAc})_{2}$ & biPy $^{d}$ & $\mathrm{Cs}_{2} \mathrm{CO}_{3}$ & DMA & 30 \\
\hline 14 & $\mathrm{Pd}(\mathrm{OAc})_{2}$ & $(\mathrm{Tol})_{3} \mathrm{P}$ & $\mathrm{Cs}_{2} \mathrm{CO}_{3}$ & DMA & 55 \\
\hline 15 & $\mathrm{Pd}(\mathrm{OAc})_{2}$ & $\mathrm{TFP}^{\mathrm{e}}$ & $\mathrm{Cs}_{2} \mathrm{CO}_{3}$ & DMA & 62 \\
\hline 16 & $\mathrm{Pd}(\mathrm{OAc})_{2}$ & $\mathrm{TCP}^{\mathrm{f}}$ & $\mathrm{Cs}_{2} \mathrm{CO}_{3}$ & DMA & 55 \\
\hline 17 & $\mathrm{Pd}(\mathrm{OAc})_{2}$ & DMEDA $^{\mathrm{g}}$ & $\mathrm{Cs}_{2} \mathrm{CO}_{3}$ & DMA & 52 \\
\hline 18 & $\mathrm{Pd}(\mathrm{dppf}) \mathrm{Cl}_{2}{ }^{\mathrm{h}}$ & $\mathrm{PPh}_{3}$ & $\mathrm{Cs}_{2} \mathrm{CO}_{3}$ & DMA & 20 \\
\hline \multicolumn{6}{|c|}{ 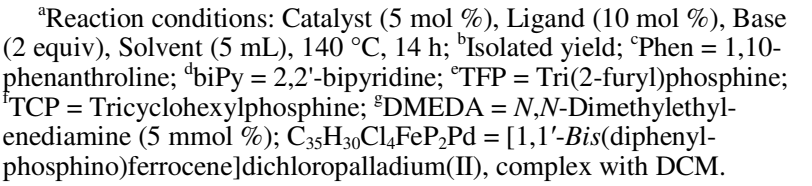 } \\
\hline
\end{tabular}

The synthetic merit of the method was demonstrated by varying the substrates for the reaction (Table 4). Various haloarenes and $\alpha$-hydroxy styrenes containing electron donating or withdrawing groups could be used for this reaction satisfactorily. For example, 1-(1-(4methoxyphenyl)vinyl)-naphthalen-2-ol (3c) reacted with $\mathbf{4 a}$ to give $\mathbf{5 b}$ in $68 \%$ yield (Table 4 , entry 2) and 7methoxy-1-(1-(4-methoxyphenyl)vinyl)-naphthalen-2-ol

(3f) reacted with $\mathbf{4 a}$ to afford $\mathbf{5 k}$ in $65 \%$ (Table 4, entry 11). Reaction of $\mathbf{3 a}$ with 4-nitroiodobenzene afforded corresponding naphthofuran $\mathbf{5 i}$ in $51 \%$ yield (Table 4, entry 9). The structures of all the synthesized 2,3diarylnaphthofurans (5a-n) were established by IR, NMR $\left({ }^{1} \mathrm{H}\right.$ and ${ }^{13} \mathrm{C}$ ) and mass spectrometry data (Supporting Information). In the ${ }^{1} \mathrm{H} \mathrm{NMR}$ of $\mathbf{5 a}$, the peak for the vinylic methylene protons and the phenolic proton of $\mathbf{3 a}$ disappeared, and only the signal for the aromatic protons were observed. Similarly, in the IR spectrum no peak was observed for the phenolic $\mathrm{OH}$ group.

The sequential hydroarylation/Heck-oxyarylation was not limited to naphthol derivatives and was also applied to the synthesis of 2,3-diarylbenzofurans from electron rich phenols. Indeed, this catalytic system also proved viable with 4-methoxyphenol (6). Reaction of $\mathbf{6}$ with $\mathbf{2 a}$ using $\mathrm{In}(\mathrm{OTf})_{3}$ under microwave irradiation for $10 \mathrm{~min}$ gave the corresponding $\alpha$-hydroxystyrene (4-methoxy-2(1-phenylvinyl)-phenol, 7) in $68 \%$ yield. The structure of 7 was elucidated by IR, ${ }^{1} \mathrm{H}$ NMR, ${ }^{13} \mathrm{C}$ NMR and mass spectrometry. In the IR, a peak for the phenolic $\mathrm{OH}$ group appeared in the region of 3417-3525 $\mathrm{cm}^{-1}$. In the ${ }^{1} \mathrm{H} \mathrm{NMR}$, peak for the vinylic and phenolic protons appeared at 5.41 and $5.85 \mathrm{ppm}$ as doublets and at $4.79 \mathrm{ppm}$ as a singlet, respectively. Reaction of $\mathbf{7}$ with $\mathbf{4 a}$ in the presence of $\mathrm{Pd}(\mathrm{OAc})_{2}(5 \mathrm{~mol} \%), \mathrm{PPh}_{3}$ and $\mathrm{Cs}_{2} \mathrm{CO}_{3}$ gave 5-methoxy2,3-diphenylbenzofuran (8) in $75 \%$ yield (Scheme 1).

Table 4. Synthesis of 2,3-Diarylnaphthofurans. ${ }^{a}$

\begin{tabular}{ccccccc}
\hline Entry & $\mathrm{R}^{1}$ & $\mathrm{R}^{2}$ & $\mathrm{R}^{3}$ & Prod. & $\begin{array}{c}\text { Time } \\
(\mathbf{h})\end{array}$ & $\begin{array}{c}\text { Yield }^{\mathrm{b}} \\
(\%)\end{array}$ \\
\hline 1 & $\mathrm{H}$ & $\mathrm{H}$ & $\mathrm{H}$ & $\mathbf{5 a}$ & 14 & 72 \\
2 & $\mathrm{H}$ & $4-\mathrm{OCH}_{3}$ & $\mathrm{H}$ & $\mathbf{5 b}$ & 12 & 68 \\
3 & $\mathrm{H}$ & $4-\mathrm{CH}_{3}$ & $\mathrm{H}$ & $\mathbf{5 c}$ & 14 & 57 \\
4 & $\mathrm{H}$ & $\mathrm{H}$ & $4-\mathrm{OCH}_{3}$ & $\mathbf{5 d}$ & 12 & 72 \\
5 & $\mathrm{H}$ & $\mathrm{H}$ & $4-\mathrm{CH}_{3}$ & $\mathbf{5 e}$ & 14 & 53 \\
6 & $\mathrm{H}$ & $4-\mathrm{CH}_{3}$ & $4-\mathrm{CH}_{3}$ & $\mathbf{5 f}$ & 14 & 50 \\
7 & $\mathrm{H}$ & $4-\mathrm{OCH}_{3}$ & $4-\mathrm{CH}_{3}$ & $\mathbf{5 g}$ & 11 & 52 \\
8 & $\mathrm{H}$ & $\mathrm{H}$ & $2-\mathrm{CH}_{3}$ & $\mathbf{5 h}$ & 14 & 51 \\
9 & $\mathrm{H}$ & $\mathrm{H}$ & $4-\mathrm{NO}_{2}$ & $\mathbf{5 i}$ & 14 & 41 \\
10 & $\mathrm{H}$ & $\mathrm{H}$ & $2,3-\mathrm{C}_{4} \mathrm{H}_{4}$ & $\mathbf{5 j}$ & 14 & 36 \\
11 & $7-\mathrm{OCH}_{3}$ & $4-\mathrm{OCH}_{3}$ & $\mathrm{H}^{-}$ & $\mathbf{5 k}$ & 10 & 65 \\
12 & $7-\mathrm{OCH}_{3}$ & $4-\mathrm{OCH}_{3}$ & $4-\mathrm{CH}_{3}$ & $\mathbf{5 l}$ & 10 & 62 \\
13 & $7-\mathrm{OCH}_{3}$ & $\mathrm{H}$ & $4-\mathrm{CH}_{3}$ & $\mathbf{5 m}$ & 11 & 56 \\
14 & $7-\mathrm{OCH}_{3}$ & $4-\mathrm{CH}_{3}$ & $4-\mathrm{CH}_{3}$ & $\mathbf{5 n}$ & 11 & 39
\end{tabular}

${ }^{\mathrm{a}}$ Reaction condition: 3 (0.81 mmol), 4 (0.975 mmol), Pd(OAc) $)_{2}(0.04$ $\mathrm{mmol}), \mathrm{Ph}_{3} \mathrm{P}(0.081 \mathrm{mmol}), \mathrm{Cs}_{2} \mathrm{CO}_{3}(1.63 \mathrm{mmol}), \mathrm{DMA}(5 \mathrm{~mL}), 140{ }^{\circ} \mathrm{C}$, $14 \mathrm{~h}$. ${ }^{6}$ Isolated yield.

Scheme 1. Synthesis of 5-methoxy-2,3-diphenylbenzofuran

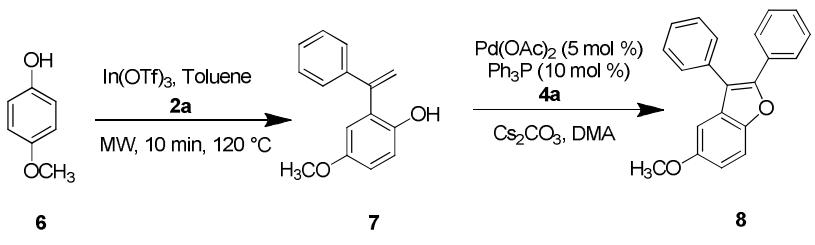

The structure of $\mathbf{8}$ was unambiguously elucidated by spectroscopic analysis. The ${ }^{1} \mathrm{H}$ NMR spectrum showed only one singlet in the aliphatic region at $3.80 \mathrm{ppm}$ for the $\mathrm{OCH}_{3}$ group, and the integration for the aromatic region was in accordance with the required 13 aromatic protons of $\mathbf{8}$. The presence of a peak at $55.98 \mathrm{ppm}$ of $\mathrm{OCH}_{3}$ group along with other 16 carbons peaks in ${ }^{13} \mathrm{C}$ NMR and molecular ion peak at 323.1065 for $[\mathrm{M}+\mathrm{Na}]^{+}$ion in HRMS, confirmed the structure of $\mathbf{8}$. The structure of $\mathbf{8}$ was further independently confirmed by an X-ray crystal structure (CCDC 923801) (Figure 2). The two aryl rings generate steric strain, and they are oriented in different planes.

Based on the structure of the product obtained and literature reports, ${ }^{29,}{ }^{30}$ the mechanism of the reaction is tentatively proposed as shown in Scheme 2. It is expected that initially 3 reacts with Ar-Pd-I to form an oxygencoordinated Pd(II)-aryl complex (9) which on insertion of alkene gives a five membered oxygen- coordinated 
palladium(II) complex (10). This intermediate on $\beta$ hydride elimination gives an intermediate with $\mathrm{OPd}^{(\mathrm{II})} \mathrm{H}$ (11). Intramolecular addition of the alkene of $\mathbf{1 1}$ to $\mathrm{OPd}^{(\mathrm{II})} \mathrm{H}$ gives the six membered oxygen-coordinated $\mathrm{Pd}(\mathrm{II})$ complex (12). Reductive elimination of 12 gives tetrahydrofuran derivative (13). Subsequent oxidation of 13 results in the formation of naphthofuran (5)/benzofuran (8).

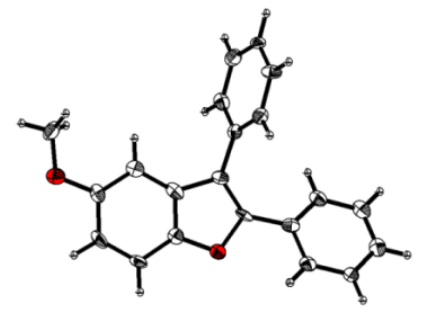

Figure 2. ORTEP diagram of 8

Scheme 3. Tentative proposed mechanism for the Heck oxyarylation.

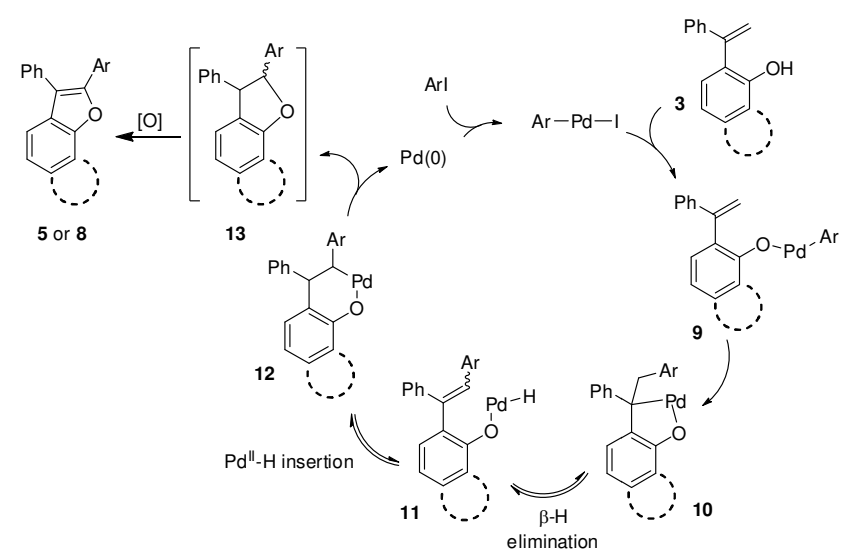

For clarity the ligands for Pd are omitted.

In conclusion, 2,3-diarylnaphthofurans were synthesized in an efficient and general synthetic strategy in good to high yield from easily available naphthols, alkynes, and iodoarenes. An interesting feature of the method is that it accommodates functional groups amenable to further manipulation and with a rapid increase in molecular complexity. Further studies are ongoing in our laboratory to expand the synthetic utility of this versatile catalytic system.

Acknowledgment. The authors thank DST-FIST for focused microwave and UGC, New Delhi for financial support via grant No. 39-733/2010 (SR). VKR thank CSIR, New Delhi for senior research fellowships.

Supporting Information Available: Experimental procedure, characterization data and copies of the ${ }^{1} \mathrm{H}$ and
${ }^{13} \mathrm{C}$ NMR of the synthesized compounds 4a-h. This material is available free of charge via the Internet at http://pubs.acs.org.

\section{References}

1. Srivastava, V.; Negi, A. S.; Kumar, J. K.; Faridi, U.; Sisodia, B. S.; Darokar, M. P.; Luqman, S.; Khanuja, S. P. S., Bioorg. Med. Chem. Lett. 2006, 16, 911-914.

2. H. Tatum, J.; A. Baker, R.; E. Berry, R., Phytochemistry 1987, 26, 2499-2500.

3. Gupta, P. P.; Srimal, R. C.; Verma, N.; Tandon, J. S., Pharm. Biol. 1999, 37, 46-49.

4. Ito, J.; Takaya, Y.; Oshima, Y.; Niwa, M., Tetrahedon 1999, 55, 2529-2544.

5. Chiummiento, L.; Funicello, M.; Lopardo, M. T.; Lupattelli, P.; Choppin, S.; Colobert, F., Eur. J. Org. Chem. 2012, 188-192.

6. Salmon, R. J.; Buisson, J. P.; Zafrani, B.; Aussepe, L.; Royer, R., Carcinogenesis 1986, 7, 1447-1450.

7. Le Guével, R.; Oger, F.; Lecorgne, A.; Dudasova, Z.; Chevance, S.; Bondon, A.; Barath, P.; Simonneaux, G.; Salbert, G., Bioorg. Med. Chem. 2009, 17, 7021-7030.

8. Gan, C.-S.; Nan, D.-D.; Qiao, J.-P.; Wang, C.-W.; Zhou, J.-N., J. Nucl. Med. 2012, 53, 1620.

9. Ye, S.; Liu, G.; Pu, S.; Wu, J., Org. Lett. 2011, 14, 70-73.

10. Moure, M. J.; SanMartin, R.; Dominguez, E., Angew. Chem. Int. Ed. 2012, 51, 3220-3224.

11. Park, K. K.; Jeong, J., Tetrahedron 2005, 61, 545-553.

12. Prasada Rao Lingam, V. S.; Dahale, D. H.; Mukkanti, K.; Gopalan, B.; Thomas, A., Tetrahedron Lett. 2012, 53, 56955698.

13. Sakiyama, N.; Noguchi, K.; Tanaka, K., Angew. Chem. Int. Ed. 2012, 51, 5976-5980.

14. Nicolaou, K. C.; Snyder, S. A.; Bigot, A.; Pfefferkorn, J. A., Angew. Chem. Int. Ed. 2000, 39, 1093-1096.

15. Hashmi, A. S. K.; Yang, W.; Rominger, F., Angew. Chem. Int Ed. 2011, 50, 5762-5765.

16. Hashmi, A. S. K.; Yang, W.; Rominger, F., Chem. Eur. J. 2012, $18,6576-6580$.

17. Arcadi, A.; Cacchi, S.; Del Rosario, M.; Fabrizi, G.; Marinelli, F., J. Org. Chem. 1996, 61, 9280-9288.

18. Colobert, F.; Castanet, A.-S.; Abillard, O., Eur. J. Org. Chem. 2005, 3334-3341.

19. Bates, C. G.; Saejueng, P.; Murphy, J. M.; Venkataraman, D., Org. Lett. 2002, 4, 4727-4729.

20. G. Kundu, N.; Pal, M.; S. Mahanty, J.; De, M., J. Chem. Soc Perkin Trans. 1 1997, 2815-2820.

21. Larock, R. C.; Yum, E. K.; Doty, M. J.; Sham, K. K. C., J. Org Chem. 1995, 60, 3270-3271.

22. Yamaguchi, M.; Hayashi, A.; Hirama, M., J. Am. Chem. Soc 1995, 117, 1151-1152.

23. J S Yadav, B. V. S. R., Synthesis 2009, 1301-1304.

24. Yamaguchi, M.; Arisawa, M.; Omata, K.; Kabuto, K.; Hirama, M.; Uchimaru, T., J. Org. Chem. 1998, 63, 7298-7305.

25. Sarma, R.; Prajapati, D., Chem. Commun. 2011, 47, 9525-9527.

26. Casiraghi, G.; Casnati, G.; Puglia, G.; Sartori, G.; Terenghi, G., Synthesis 1977, 122-124.

27. Mendoza, P. D.; Echavarren, A. M., Pure Appl. Chem. 2010, 82, 801-820.

28. Yoon, M. Y.; Kim, J. H.; Choi, D. S.; Shin, U. S.; Lee, J. Y.; Song, C. E., Adv. Synth. Catal. 2007, 349, 1725-1737.

29. Zhu, C.; Falck, J. R., Angew. Chem. Int. Ed. 2011, 50, 66266629.

30. Cacchi, S.; Fabrizi, G.; Goggiamani, A.; Iazzetti, A.; Madec, D.; Poli, G.; Prestat, G., Org. Biomol. Chem. 2011, 9, 8233-8236. 